\title{
A Rare Case of Empedobacter Brevis Cutaneous Infection Treated Successfully
}

\section{with Oral Sarecycline}

\author{
Susuana Adjei, MD¹; Austinn C. Miller, MD 1; Laurie A. Temiz, BA² ; Stephen K. Tyring, MD, PhD, MBA 1,3
}

${ }^{1}$ Center for Clinical Studies Webster, TX; ${ }^{2}$ Meharry Medical College, Nashville, TN; ${ }^{3}$ UT Houston Department of Dermatology, Houston TX

\section{INTRODUCTION}

Empedobacter brevis, as a part of the Flavobacteriaceae family, is a non-motile, strictly aerobic, gram negative, yellow colony-forming bacterium that typically resides in soil, plants, water sources, and hospital environments. ${ }^{1,2}$

The first reported case of a human infection was in 2002 when 11 out of 12 patients were diagnosed with endophthalmitis from an E. brevis infection post cataract surgery. ${ }^{3}$

More cases of $\mathrm{E}$. brevis infections have since been reported ranging from meningitis to cellulitis. $3,4,6$ Treatment can be complicated by the bacteria's beta lactamase gene, which results in resistance to extended cephalosporins and carbapenems. ${ }^{5}$ There have been a few dermatologic manifestations of $\mathrm{E}$. Brevis infections reported in the literature that warrant further evaluation. ${ }^{6,7}$

We present a case of an E. brevis infection in a 61-year-old male who presented with a persistent right mid-thigh lesion.



to extended cephalosporins and carbapenems, as demonstrated by the sensitivities from our patient.
Table 1. Reported cases of skin infections due to $E$. Brevis

\section{CASE PRESENTATION}

A 61-year-old male with a past medical history of hypertension, actinic keratoses, history of valve replacement (chronically on Warfarin) and prior knee replacement surgery presented with a lesion that persisted for 6 weeks after doing yard work. He reported using hydrogen peroxide and antibiotic bandages with no improvement.

\section{Physical Exam}

\begin{tabular}{c|l}
\hline Culture & $\begin{array}{l}\text { erosion with honey-yellow crusting. } \\
\text { - Empedobacter brevis was identified by DNA } \\
\text { - Resistant to meropenem and tobramycin }\end{array}$ \\
\hline Treatment & $\begin{array}{l}\text { Patient was initially treated with mupirocin with no } \\
\text { improvement. 15-day course of } 150 \mathrm{mg} \text { once-daily. } \\
\text { Sarecycline was added after the results returned and the } \\
\text { lesion healed well over the upcoming weeks. }\end{array}$ \\
\hline
\end{tabular}


Conflict of Interest Dr. Stephen K. Tyring is a Principal Investigator for a Clinical Trial for one of Almirall's trials.

\section{ACKNOWLEDGEMENTS}

We would like to thank the patient for providing permission to report his case.

\section{REFERENCES}

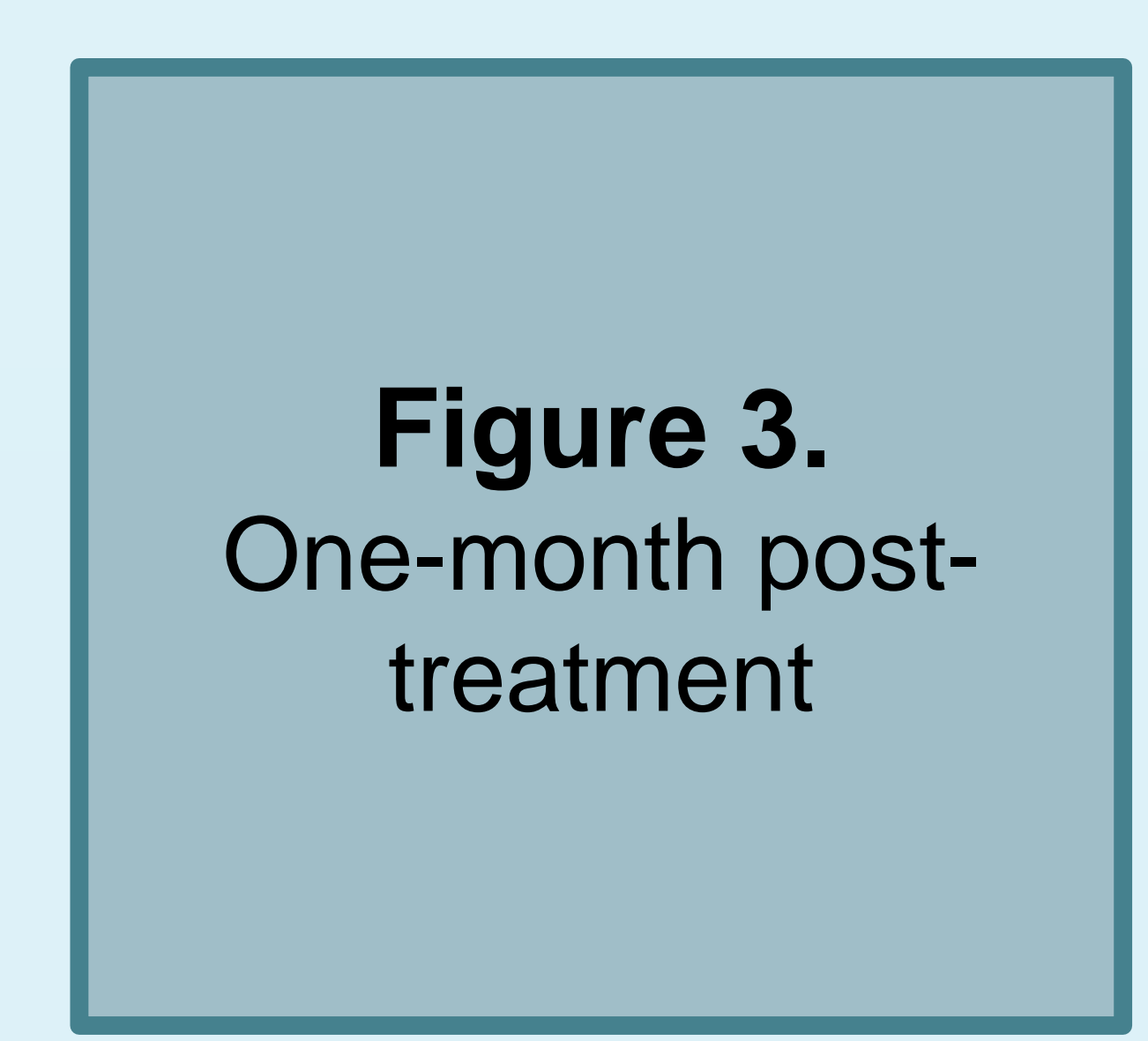

